City University of New York (CUNY)

CUNY Academic Works

\title{
A Conceptual Content Analysis of 75 Years of Diversity Research in Public Administration
}

Maria J. D'Agostino

CUNY John Jay College

\section{How does access to this work benefit you? Let us know!}

More information about this work at: https://academicworks.cuny.edu/jj_pubs/284

Discover additional works at: https://academicworks.cuny.edu

This work is made publicly available by the City University of New York (CUNY).

Contact: AcademicWorks@cuny.edu 


\title{
A Conceptual Content Analysis of 75 Years of Diversity Research in Public Administration
}

Review of Public Personnel Administration 2018, Vol. 38(2) 248-267

(C) The Author(s) 2016

Reprints and permissions: sagepub.com/journalsPermissions.nav DOI: $10.1177 / 073437 \mid \times 16671368$ journals.sagepub.com/home/rop

(S)AGE

\section{Meghna Sabharwal', Helisse Levine², and Maria D'Agostino ${ }^{3}$}

\begin{abstract}
Diversity is an important facet of public administration, thus it is important to take stock and examine how the discipline has evolved in response to questions of representative democracy, social equity, and diversity. This article assesses the state-of-the-field by addressing the following question: How has research on diversity in the field of public administration progressed over time? Specifically, we seek to examine how the focus of diversity has transformed over time and the way the field has responded to half a century of legislation and policies aimed at both promoting equality and embracing difference. We utilize a conceptual content analysis approach to examine articles published on diversity in seven key public administration journals since 1940. The implications of this study are of great importance given that diversity in the workplace is a central issue for modern public management.
\end{abstract}

\section{Keywords}

diversity, representative bureaucracy, gender, race, conceptual content analysis, public administration journals

\section{Introduction}

We live in a society, which has become more complex and diverse than ever before, where people are categorized not only according to their race and gender but

\footnotetext{
IThe University of Texas at Dallas, Richardson, TX, USA

2Long Island University, Brooklyn, NY, USA

${ }^{3}$ City University of New York, New York City, NY, USA

\section{Corresponding Author:}

Meghna Sabharwal, The University of Texas at Dallas, School of Economic, Political and Policy Sciences, Public and Nonprofit Management, 800 W. Campbell Road GR 3I, Richardson, TX 75080-302I.

Email: meghna.sabhrwal@utdallas.edu
} 
also according to their ethnicity, nationality, socioeconomic class, sexual orientation, political affiliation, educational attainment, religion, physical ability, and even generational cohort. All these attributes comprise what we term as diversity. Indeed, diversity over the past two decades has become an important facet of public administration (PA). For example, preoccupation with issues of equality and justice led researchers to identify social equity as the third pillar of public administration alongside efficiency and effectiveness (Frederickson, 1980, 1990, 2005; Riccucci, 2002, 2009; Rosenbloom, 1977, 2005). Research has shown that organizations perform better when they are diverse (Hewins-Maroney \& Williams, 2013; Pitts, 2009) and inclusive (Sabharwal, 2014). Also documented is that large innovative organizations that are more diverse are also more successful (Caleb, 2014).

However, public administration research has not always reflected issues of diversity. In the early 1900s, for example, diversity research in public administration was nonexistent at best. With the passage of the Civil Rights Act in 1964 race and gender became more prominent and as a result, researchers started paying attention to the challenges associated with minorities and women. In the 1970s, the discussion of diversity emerged as changing the Black/White dynamic, yet not much attention was given to women and other groups until the 1980s when women began voicing concerns about their lack of representation in leadership positions (Broadnax, 2010). Most recently, we have begun to see unprecedented women and minority representation in public office such as the election of the first African American President, Chief Justice Sonia Sotomayor, the first Hispanic female on the U.S. Supreme Court, and Valerie Jarrett, a Black female who serves as assistant to the President of the United States. Moreover, the increase in diversity among government organizations has paralleled a changing culture and society (e.g., globalization, immigration, and biracial individuals and families) with gender and color no longer the predominate measure of diversity as religion, ethnicity, sexual identify, language, religion, and educational background grow in importance (Broadnax, 2010).

Therefore, what we do know is that diversification of public organizations in practice has improved their capacity to deliver services to the diverse populations being served (Broadnax, 2010). However, what remains unclear is whether public administration diversity research has kept pace with societal changes in general (e.g., legal, social, political, and economic) and the impact of that research on public administration practice specifically. Pitts and Wise (2010) argued that most research produced on the topic of diversity in public administration was descriptive with little or no information provided to managers to improve work-related outcomes. The authors argued for the need for more data to validate their findings, which were limited at that time to articles published in key public administration journals from 2000 to 2008 . Our study goes beyond this constraint and examines all articles published on the subject of diversity in seven key journals from their inception. To further validate the findings of Pitts and Wise, we also differentiate the type of research into descriptive and empirical.

This article assesses the state-of-the-field by addressing the following questions: How has research on diversity in the field of public administration progressed over time? Specifically, we seek to examine how the focus of diversity has transformed and 
the way the field has responded to half a century of legislation and policies aimed at both promoting equality and embracing difference. We utilize a conceptual content analysis methodology to examine articles on diversity in the top public administration journals. It is important to take stock and examine how the public administration discipline has evolved in response to questions of social equity and diversity (Raadschelders \& Lee, 2011). The implications of this study are considerable given that diversity in the workplace is a central issue for modern public management. For example, the recent landmark Supreme Court case (Obergefell v. Hodges, 2015) in which same sex marriage was legalized is a step in the right direction. However, several barriers remain as people of color and the LGBT (lesbian, gay, bisexual, and transgender) community continue to face racial profiling and discrimination. It is thus important that public, health, and nonprofit administrators understand the relevance of diversity to their profession. Diversity is often affiliated with race and gender. However, the results of our study will help glean whether public administration as a discipline has cultivated a broader view of diversity that extends beyond issues of women, minorities, affirmative action (AA) and representative bureaucracy.

\section{Literature Review}

Given the changing demographics and its impact on public service, diversity research is now a critical area of public administration scholarship (Carrizales \& Gaynor, 2013). Until the 1990s, most research on the topic of diversity focused on AA, equal employment opportunity (EEO), and representative bureaucracy (Grabosky \& Rosenbloom, 1975; Kellough, 1990; Meier, 1975; Pitts, 2009; Rosenbloom, 1977). The approach was normative with little emphasis on management mechanisms that might help promote outcomes for diverse employees in the work setting. The search for representation of diverse interests within public organizations at the time was driven largely by the belief that bureaucracy would serve democratic principles better if it reflected the demographic characteristics of citizens (Rourke, 1978). Representation of diverse groups, in other words, helped to ensure pluralism in the implementation of public policies and programs (Denhardt $\&$ deLeon, 1995). Based on these normative suppositions, a large number of studies investigated the degree to which the bureaucracy reflects the composition of the larger population (see, for example, Hall \& Saltzstein, 1977; Kellough, 1990; Nachmias \& Rosenbloom, 1973) and the factors that influence the prevalence of minority bureaucrats (see, for example, Cornwell \& Kellough, 1994; Mladenka, 1991; Welch, Karnig, \& Eribes, 1983). While important in its own right, the interest in passive bureaucratic representation has typically been motivated by the belief that shared demographic characteristics, and thus values, between minority bureaucrats and citizens would ultimately lead the former to pursue policies that benefit the latter (Pitkin, 1967). Meier and Stewart (1992) outlined a set of conditions whereby this transformation would most likely occur, suggesting that the definition of the issue to a particular demographic group and control by the bureaucrat of outputs that can directly benefit that group are both important factors. Meier (1993) recognized that bureaucrats that benefit those with similar demographic origins should 
translate shared values into programs, policies, and decisions. Research confirmed that minority bureaucrats use their discretion to benefit minority clients in a host of settings, including the Equal Employment Opportunity Commission (Hindera, 1993), education organizations (Meier, Stewart, \& England, 1989; Meier, Wrinkle, \& Polinard, 1999), and the Farmers Home Administration (Selden, 1997).

However, much of the recent work on representative bureaucracy has turned its attention away from the simple existence of passive or active representation and toward factors that may moderate the link between shared demographic characteristics and purposive bureaucratic action. This line of inquiry has demonstrated that representation is enhanced when institutional structures provide opportunities for minority bureaucrats at both the street and administrative levels (Keiser, Wilkins, Meier, \& Holland, 2002) and encourage greater discretion among minority bureaucrats (Meier $\&$ Bohte, 2001). Other work has emphasized the importance of attitudes and perceptions and determined that the degree to which minority bureaucrats perceive of themselves as racial representatives (Selden, 1997; Selden, Brudney, \& Kellough, 1998) and the amount of discretion that they believe they have (Sowa \& Selden, 2003) both moderate representation.

In addition to invigorated research along the lines of representative democracy, public organizations have begun to formulate new and formalized programs to "manage diversity." Recent research on diversity is thus emphasizing ways in which a diverse workforce should be managed with a focus on performance (Pitts, 2009). Thus, there are three main diversity-related research strands in public administration (Groeneveld \& Van de Walle, 2010), one that emerged as a concern for democratic representation away from the elitism that existed in the British civil service (Kingsley, 1944). The second stream built on the work of Kingsley and demonstrated that a bureaucracy that is representative of the society (passive representation) and promotes the interests of those represented (active representation) is a legitimate form of democracy (Krislov, 1974; Mosher, 1982). As the bureaucracy became diverse, concerns regarding managing diversity emerged as the third stream of research.

Thomas (1990) moved beyond a discussion of diversity as simply race and ethnicity to one that focused on managing diversity. He defined managing diversity as "the process of creating and maintaining an environment that naturally enables all participants to contribute to their full potential in focused pursuit of organizational objectives" (p. 112). He also argued that managing for diversity meant managing for all differences. This meant focusing on making sure all groups of employees, based on race, ethnicity, gender, education, or function, had what they needed to succeed at work. Diversity management is different from AA and EEO in that it is about what managers do on the job on a day-to-day basis, and the programs that organizations implement to best serve diverse employees. Gilbert and Ivancevich (2000) defined it as "the systematic and planned commitment by organizations to recruit, retain, reward, and promote a heterogeneous mix of employees" (p. 75). Pitts (2006) argued that "diversity management is a multifaceted concept" that includes recruitment programs, programs aimed to increase cultural awareness, and pragmatic management policies. Managing diversity is thus a proactive approach that goes beyond AA by recognizing 
the benefits of diversity as a whole rather than targeting specific groups. To realize these efforts, support from upper management is vital in creating an environment in which each employee's full potential is realized.

Diversity management has been characterized as a component of human resource management (Mathews, 1998), and the policies and programs that make up the diversity management function vary significantly between organizations, involving training programs, family-friendly policies, mentoring opportunities, and advocacy groups (Kellough \& Naff, 2004). Kellough and Naff (2004) reported that nine out of 10 federal agencies have initiated a program for diversity management. Diversity management has also evolved into a consulting industry, with both practitioners and academics contracting with organizations to evaluate their diversity efforts. Yet, there is very little empirical research that investigates the link between diversity and performance, and that line of work has produced conflicting results at best (Andrews, Boyne, Meier, O'Toole, \& Walker, 2005; Pitts, 2005, 2006; Pitts \& Jarry, 2005). Moreover, aside from conceptual work, there has been no empirical assessment of the relationship between diversity management and work-related outcomes (Pitts, 2006).

Sabharwal (2014) advanced the argument on the impact of diversity management and performance in the public sector. The author finds that standard policies implemented by organizations to manage diversity (such as incorporating diversity into the mission statement of an organization; having mentoring and work/life balance programs; family-friendly policies like flexible hours, telecommuting, alternative work arrangements; and linking diversity to the organizations' strategic mission) while important were insufficient to enhance performance. Creating an environment in which employees' opinions were sought in making decisions thus giving them a voice in the decision-making process were most important in improving performance. These strategies go beyond just managing for diversity to inclusion of diverse people in the organization. Inclusion is thus defined as the "the degree to which individuals feel part of critical organizational processes" (Mor Barak \& Cherin, 1998, p. 48). Inclusive environments create higher productivity and job commitment (Cho \& Mor Barak, 2008; Mor Barak \& Levin, 2002; Sabharwal, 2014). Women and minorities who feel excluded at work often times report lower job commitment (Findler, Wind, \& Mor Barak, 2007). Thus, inclusive environments are those in which all employees are valued and feel safe to express their multiple identities at work (Ferdman et al., 2010). The success of inclusion practices is fostered by leaders who are committed to achieving an environment wherein everyone's opinion matters (Sabharwal, 2014).

In addition, diversity management and representative bureaucracy are part of the third pillar of public administration - social equity (Gooden \& Portillo, 2011). Social equity is a practical tool in public administration that can be used to make equity-based decisions. It is defined as promoting "equality in a society with deep social and economic disparities. It embodies the goal that the members of all social groups will have the same prospects for success and same opportunity to be protected from the adversities of life" (Johnson, Johnson, \& Svara, 2015, p. 3). Issues of equality, justice, and fairness have been central to public administration since the "Declaration of Independence," which set forth the principle that "all men are created equal." The field 
of public administration despite holding equity as its prime most values continues to grapple with ways and means to achieve equity. The research on diversity has for the longest time focused on AA, EEO, and representative bureaucracy (Kellough, 1990; Meier, 1975, 1993; Meier \& Nigro, 1976; Rosenbloom, 1977). The main goal of these programs was to avert legal ramifications that could result as a consequence of discrimination in hiring, promoting, and advancing people of color and women in organizations. Since the 1990s, the idea of diversity emerged that emphasized respecting and valuing differences in all its forms. The field of public administration research has evolved from thinking of diversity in purely legalistic terms to emphasizing the benefits of a diverse workplace and society. In doing so, it continues to make use of the representative bureaucracy framework and has recently incorporated the concept of diversity management. Diversity management literature though in its nascency in public administration will continue to grow as the society and its needs become diverse. Another stream of research that is gaining traction is inclusion. Future research can utilize the lens of diversity management and inclusion as ways to deliver equitable public services.

Pitts (2011) argued that research has not moved forward to focus on how and which tools can be used to advance social equity outcomes. Representative bureaucracy and managing diversity can be used to improve social equity but we need to move beyond race and gender and empirical research is necessary to identify and better understand what works in terms of alleviating inequities. Despite the call for more "practice-oriented" research, existing research has produced little "usable knowledge" (Pitts \& Wise, 2010; Wise \& Tschirhart, 2000). The following section describes the data and method used to examine how the focus of diversity has transformed over time.

\section{Data and Method}

This study uses a conceptual content analysis approach to analyze articles on diversity published in seven key public administration journals. Conceptual content analysis is a research tool that helps quantify the number of times a word/phrase or text appears in a document. It is a form of content analysis - "a tool that is used to determine the presence of certain words or concepts within texts or sets of texts" (Christie, 2007). Usually a concept is chosen for examination and its occurrence in the documents is tallied. In the context of this study, the term Diversity and its various components were examined. The unit of analysis is published journal articles. A search was performed in the abstract or in the full text for the key word "diversity" in seven public administration journals: American Review of Public Administration (ARPA) from 1967 to 2013, Public Administration Review (PAR) from 1940 to 2013, Administration and Society (A\&S) from 1969 to 2013, Public Personnel Management (PPM) from 1973 to 2013, Journal of Public Administration Research and Theory (JPART) from 1991 to 2013, Review of Public Personnel Administration (ROPPA) from 1980 to 2013, and Public Performance and Management Review (PPMR) from 1975 to 2013, formally known as Public Productivity Review and Public Productivity Management Review. Data were captured from the inception of each journal. We identified a total of 2,315 
journal articles that had the word diversity in either the abstract or the full text of the article.

Two graduate students were hired as coders and trained in the coding process. After a period of training, the two students independently coded articles as a pilot test. Actual coding only began after the coders achieved an intercoder reliability of 0.8 . The articles were coded on several dimensions of diversity. However, first the relevance of the article was established. While all of the 2,315 articles had the word "diversity" in either the abstract or the full text, they were not always relevant to the study. For example, an article mentioned the term diversity, but not in the context that was useful to our study - "Hoffman (1978) finds a growing diversity of theoretical approaches; and Miller (1976) discovers a new model of administrative processes." In this example, the article was coded as nonrelevant. Another example is, "This loosening of the system occurs through increasing the number of assets as well as the diversity in the system." In many cases, diversity was used as a term that signified variety not necessarily in terms of race, ethnicity, gender, sexual orientation, religion, ability, or the other dimensions that typically constitute individual differences and similarities. Only full-length journal articles were coded; book reviews, professional notes, and response to articles were not included. Of the 2,315 articles, only $15 \%$ were relevant to our study $(N=348)$.

The various dimensions of diversity that were coded in this study include race (ethnicity/minority), gender, AA/EEO, representative bureaucracy, age, disability, religion, socioeconomic status (SES), sexual orientation, immigration, generations, veterans, diversity management, cultural competency (including culture), and other. A number of articles fit more than one dimension of diversity. For example, an article usually discusses race, gender, and $\mathrm{EEO} /$ Affirmative action in conjunction, and thus gets a code of 1 under each dimension. For this reason, the overall dimensions coded are larger than the total number of articles. The articles were coded for "what" was analyzed, rather than "how" they were interpreted. For example, an article can discuss race without mentioning anything about representative bureaucracy. In this case, race is coded as 1 and representative bureaucracy as 0 . Unless the article explicitly discussed issues of representative bureaucracy, that dimension received a code of 0 .

Other elements coded in this study include the following: type of study $(1=$ United States; $0=$ international), year of publication, author details that took into account the number of author(s), gender of author(s), rank of author(s), affiliation of author(s), and their profession, whether the author(s) is an academic, practitioner, or student or other. Rank of authors was coded as follows: $1=$ assistant professor; 2 = associate professor; $3=$ professor; $4=$ other. Other includes lecturer, adjunct, instructor, and student, usually anyone who is not tenured or on a tenure track. We also coded the methodology used in the study ( 1 = quantitative; 2 = qualitative; $3=$ mixed; $4=$ other). If the data were quantitative, we coded for the data source, which included primary or secondary. If the data were classified as qualitative, we further coded them as case studies, interviews, content analysis, literature reviews, legal court cases or other. The site where the study was conducted was also coded. Study sites include local/municipality, state, federal, nonprofit, educational institutions, and other. 
Finally, we coded the type of research, whether descriptive or empirically related to outcomes. Descriptive studies primarily provide explanations to further the knowledge about a phenomenon under study. The goal of a descriptive study is usually to examine how things are and how they have been, but will not make policy recommendations or impact organizational outcomes. Descriptive articles usually summarize the existing studies and their findings (Shields \& Rangarajan, 2013). These studies can be qualitative or quantitative in nature. Quantitative descriptive studies might present data on race and gender that can be tabulated and plotted along a continuum. However, studies that are empirically related to outcomes aim to assess the impact of diversity on an organization or assess its relationship with an organizational outcome. Such articles assess the impact of a diverse workforce (for any of the aforementioned dimensions of diversity) on job satisfaction or performance or organizational commitment or retention or turnover or any organizational outcome. Research empirically related to outcomes often leads to some organizational impact. A study was classified as empirically related to outcomes even if diversity or diversity management was used as a dependent variable.

Kappa statistic was used to calculate intercoder reliability on all study dimensions. This is computed to determine consistency of coding between the two coders. The interrater reliability for the study ranged from 0.6 to $0.85, p<.001$. Most statisticians prefer kappa values to be at least .6 and most often higher than 0.7 before claiming a good level of agreement (Muñoz \& Bangdiwala, 1997). As such, the study satisfies the test for reliability.

\section{Results and Discussion}

\section{Diversity Dimensions Coded in the Study}

The descriptive statistics of the various dimensions coded in this study are presented in Table 1. As seen from the table, an overwhelming majority of the studies are conducted in the United States, while about $7 \%$ of the studies in our sample were conducted outside of the United States, a very small proportion were comparative - that utilized both U.S. and the international data. The journal that published the highest proportion of diversity-related research is PAR followed by PPM. PAR is the flagship journal of the American Society for Public Administration, which is the largest professional association for public administration scholars and practitioners. PAR is also the oldest journal in the discipline; in 2015, it celebrated its 75th anniversary. Given that $P A R$ is the oldest and an eminent journal in the field, it is not surprising that it tops the list as an outlet for scholars to publish their work on issues of diversity. PPM and $R O P P A$ are two other journals that published research related to diversity. These are journals specifically related to personnel issues in public administration and are key outlets for research related to workforce issues. The results are similar to what Pitts and Wise (2010) reported in their study. However, they only reported articles published on the topic from 2000 to 2008. More than half of the articles published in $A \& S$ on diversity were from 2000 to 2009; similar patterns were found in ARPA and JPART. 
Table I. Descriptive Statistics of Variables Coded in the Study.

\begin{tabular}{|c|c|c|}
\hline & Frequency (\%) & $n$ \\
\hline \multicolumn{3}{|l|}{ Type of study } \\
\hline U.S.-based & 91.7 & 319 \\
\hline International & 7.2 & 25 \\
\hline U.S. and International & I.I & 4 \\
\hline \multicolumn{3}{|l|}{ Journal } \\
\hline Administration and Society (A\&S) & 10.3 & 36 \\
\hline American Review of Public Administration (ARPA) & 6.6 & 23 \\
\hline Journal of Public Administration Research and Theory (JPART) & 6.6 & 23 \\
\hline Public Administration Review (PAR) & 30.2 & 105 \\
\hline Public Personnel Management (PPM) & 23.9 & 83 \\
\hline Public Performance and Management Review (PPMR) & 5.7 & 20 \\
\hline Review of Public Personnel Administration (ROPPA) & 16.7 & 58 \\
\hline \multicolumn{3}{|l|}{ Year of publication } \\
\hline $1960-1969$ & 0.6 & 2 \\
\hline $1970-1979$ & 6.0 & 21 \\
\hline $1980-1989$ & 4.9 & 17 \\
\hline $1990-1999$ & 30.7 & 107 \\
\hline $2000-2009$ & 42.0 & 146 \\
\hline $2010-2013$ & 15.8 & 55 \\
\hline \multicolumn{3}{|l|}{ Gender of author } \\
\hline Female & $4 I .4$ & 144 \\
\hline Male & 58.0 & 202 \\
\hline \multicolumn{3}{|l|}{ Number of author(s) } \\
\hline Sole & 52.9 & 284 \\
\hline Co-authored & 47.1 & 164 \\
\hline \multicolumn{3}{|l|}{ Rank of author } \\
\hline Assistant professor & 24.7 & 86 \\
\hline Associate professor & 20.1 & 70 \\
\hline Professor & 18.4 & 64 \\
\hline \multicolumn{3}{|l|}{ Methodology } \\
\hline Quantitative & 46.8 & 163 \\
\hline Qualitative & 46.6 & 162 \\
\hline Mixed & 4.6 & 16 \\
\hline \multicolumn{3}{|l|}{ Study site } \\
\hline Federal & 29.3 & 102 \\
\hline State & 19.8 & 69 \\
\hline Local & 22.1 & 77 \\
\hline Nonprofits & 2.5 & 9 \\
\hline Educational institutions & 10.1 & 35 \\
\hline \multicolumn{3}{|l|}{ Dimensions of diversity } \\
\hline Race & 62.6 & 218 \\
\hline Gender & 55.5 & 193 \\
\hline
\end{tabular}


Table I. (continued)

\begin{tabular}{lcr}
\hline & Frequency (\%) & $n$ \\
\hline EEO/affirmative action & 29.3 & 102 \\
Age & 20.7 & 72 \\
Representative bureaucracy & 17.5 & 61 \\
Religion & 8.9 & 31 \\
Socioeconomic status & 8.3 & 29 \\
Disability & 7.2 & 25 \\
Sexual orientation & 7.2 & 25 \\
Diversity management & 6.0 & 21 \\
Immigration & 4.6 & 16 \\
Generations & 4.9 & 17 \\
Veterans & 2.3 & 8 \\
Cultural competency & 0.3 & 1 \\
Type of research & & \\
Descriptive & 77.0 & 268 \\
Empirically related to outcomes & 21.6 & 75 \\
\hline
\end{tabular}

Note. EEO = equal employment opportunity.

\section{Diversity Research Across Journals}

The detailed results by decade and journal type are presented in Table 2 . The bulk of the diversity research has been published from 1990 onwards $(88.5 \%)$, with $58 \%$ of the articles published post 2000. The majority of the authors in our sample are male and most publications are sole authored. The results are consistent with past studies that report similar trends (Corley \& Sabharwal, 2010; Kellough \& Pitts, 2005; Raadschelders \& Lee, 2011).

Interestingly, an equal split was found between the types of methodology (quantitative or qualitative) used to study various dimensions of diversity. The majority of the quantitative studies used primary data $(63.2 \%)$; the remaining used secondary data sets. Close to half of the articles (47\%) in our sample were qualitative in nature, and a majority of them were based on literature reviews (71\%). These studies were descriptive in nature and used existing data to describe a phenomenon or present trends over time on topics mostly related to race/ethnicity and gender. About $15 \%$ of the qualitative studies were legal court cases and a similar percentage used interviews as a data collection tool. Close to one third of the studies in our sample was conducted using federal-level data. Federal-level data are made widely available for research; these data usually come from the Office of Personnel Management, Merit Systems Protection Board, U.S. Census, Bureau of Labor Statistics, and the like. Over three fourths of the articles were descriptive in nature; only $22 \%$ of the published research assessed the impact of any dimension of diversity on an organizational outcome.

On analyzing various dimensions of diversity over time, a predictable pattern emerged. A majority of the studies focused on issues of race followed by gender, EEO/ 
Table 2. Journal Publication by Decade.

\begin{tabular}{lccccccc}
\hline Journal name (start year) & $1960-1969$ & $1970-1979$ & $1980-1989$ & $1990-1999$ & $2000-1909$ & $2010-2013$ & Total (\%) \\
\hline $\begin{array}{c}\text { Public Administration } \\
\text { Review (1940) }\end{array}$ & 1 & 16 & 10 & 25 & 44 & 9 & $105(30.2)$ \\
$\begin{array}{c}\text { Public Personnel } \\
\text { Management (1973) }\end{array}$ & - & 1 & 2 & 34 & 35 & 11 & $83(23.9)$ \\
$\begin{array}{c}\text { Review of Public Personnel } \\
\text { Administration (1980) }\end{array}$ & - & - & 3 & 28 & 20 & 7 & $58(16.7)$ \\
$\begin{array}{c}\text { Administration and Society } \\
\quad(1969)\end{array}$ & 1 & 3 & - & 4 & 19 & 9 & $36(10.3)$ \\
$\begin{array}{c}\text { American Review of Public } \\
\text { Administration (1967) }\end{array}$ & - & 1 & 2 & 2 & 12 & 6 & $23(6.6)$ \\
$\begin{array}{c}\text { Jurnal of Public } \\
\text { Administration Research } \\
\text { and Theory (1991) }\end{array}$ & - & - & - & 1 & 10 & 12 & $23(6.6)$ \\
$\begin{array}{c}\text { Public Performance and } \\
\text { Management Review } \\
\text { (I975) }\end{array}$ & - & - & - & 13 & 6 & 1 & $20(5.7)$ \\
\hline
\end{tabular}

AA, age, and representative bureaucracy. We found 218 articles that focused on issues related to people of color and ethnicity followed by 193 articles that published on sex/ gender-related topics. More than 100 articles addressed AA issues. These results are consistent with previous studies (Pitts \& Wise, 2010; Wise \& Tschirhart, 2000). Studies related to age have gained momentum since Pitts and Wise published their study in 2010, which correlates with the growing concern about the impending retirements and graying of the public sector workforce. PPM published the highest proportion of age-related articles across all journals; it also topped the list for publications that addressed issues of AA, disability, sexual orientation, religion, immigration, veterans, generations, diversity management, and cultural competency. $P A R$ followed by JPART had the highest proportion of articles addressing issues of representative bureaucracy. PAR published the highest proportion of articles related to race/ethnicity, gender, representative bureaucracy and SES.

\section{Diversity Research by Decade}

Table 3 further examines the various dimensions of diversity used in the study across decade. The majority of the research across all dimensions was conducted from 2000 through 2009 (e.g., 43.89\%) followed by the years 2010 through 2013 averaging $16.42 \%$. Diversity research gained steam in the 1990 s (25.65\% of all dimensions) with the push away from tolerating diversity and following legal mandates to recognizing the importance of a diverse workforce. Thomas (1990) was the first to coin the term managing for diversity, which argued that neither valuing diversity nor complying by AA/EEO laws was sufficient in fully realizing the benefits of a diverse workforce. While Title VII of the Civil Rights Act was passed in 1964 prohibiting discrimination on grounds of race, color, religion, sex or national origin, not much research related to diversity was published during this decade. As seen from our results, diversity as a 
Table 3. Difference of Means by Dimensions of Diversity and Years.

\begin{tabular}{|c|c|c|c|c|c|c|}
\hline $\begin{array}{l}\text { Diversity dimension } \\
\text { (n) }\end{array}$ & $\begin{array}{c}1960-1969 \\
(\%)\end{array}$ & $\begin{array}{c}1970-1979 \\
(\%)\end{array}$ & $\begin{array}{c}1980-1989 \\
(\%)\end{array}$ & $\begin{array}{c}1990-1999 \\
(\%)\end{array}$ & $\begin{array}{c}2000-2009 \\
(\%)\end{array}$ & $\begin{array}{c}2010-2013 \\
(\%)\end{array}$ \\
\hline Race $(2 \mid 8)$ & 0.5 & 7.8 & 4.6 & 28.4 & 41.3 & 17.4 \\
\hline Gender* (193) & - & 4.7 & 6.2 & 36.8 & 36.3 & 16.1 \\
\hline $\begin{array}{r}\text { EEO/affirmative } \\
\text { action** (102) }\end{array}$ & - & 4.9 & 9.8 & 38.2 & 39.2 & 7.8 \\
\hline Age (72) & - & 2.8 & 6.9 & 29.2 & 41.7 & 19.4 \\
\hline $\begin{array}{l}\text { Representative } \\
\text { bureaucracy** } \\
(61)\end{array}$ & - & 6.6 & 4.9 & 9.8 & 54.1 & 24.6 \\
\hline Religion* (3I) & 3.2 & 6.5 & - & 16.1 & 61.3 & 12.9 \\
\hline $\begin{array}{l}\text { Socioeconomic } \\
\text { status* }(29)\end{array}$ & 3.4 & 17.2 & 3.4 & 17.2 & 48.3 & 10.3 \\
\hline Disability (25) & - & 4.0 & 4.0 & 36.0 & 32.0 & 24.0 \\
\hline $\begin{array}{l}\text { Sexual orientation* } \\
\text { (25) }\end{array}$ & - & - & - & 24.0 & 40.0 & 36.0 \\
\hline $\begin{array}{l}\text { Diversity } \\
\text { management }(2 \mathrm{I})\end{array}$ & - & - & - & 23.8 & 42.9 & 33.3 \\
\hline Immigration* (16) & 6.3 & - & - & 43.8 & 31.3 & 18.8 \\
\hline Generations (I7) & - & 5.9 & - & 17.6 & 64.7 & 11.8 \\
\hline Veterans (8) & - & - & 12.5 & 12.5 & 37.5 & 37.5 \\
\hline $\begin{array}{l}\text { Cultural } \\
\text { competency (I) }\end{array}$ & - & - & - & - & - & 100.0 \\
\hline
\end{tabular}

Note. Difference of means is recorded between groups. $n$ is in the parentheses in the first column. $\mathrm{EEO}=$ equal employment opportunity.

$* p<.05 . * * p<.01$.

term was clearly not used in the context of race or other dimensions across the 1960s, 1970 s, and 1980s. The results would probably be different if we performed key word searches on each dimension of diversity. However, that is beyond the purview of this research.

Diversity research emerged from the shadows of AA and was seen as something beyond race and gender. As such, other dimensions of diversity such as age, religion, sexual orientation, veteran status, disability, generational differences and so on started to gain focus. This combined with the changing demographics in the United States led to an escalation of research in the new millennium. However, diversity research does not seem to have moved past AA, as it continues to be widely written and researched in the 1990s and 2000s. With several landmark cases involving educational institutions, AA research continues to be hotly debated in higher education. The $2003 \mathrm{Gratz}$ v. Bollinger and Grutter v. Bollinger, both University of Michigan cases remain as landmark decisions after the 1978 Bakke v. Regents of the University of California case. Most recently, Fisher v. University of Texas at Austin case was heard in the U.S. Supreme Court and was sent back to the fifth circuit court for further consideration, in 
which the lower courts ruled in favor of the institution. The case remains to be further appealed by the defendant. Given the contentious nature of these debates, AA will most likely continue to be researched by scholars in public administration.

With the passage of the Family Medical Leave Act in 1993 and the focus on issues of glass ceiling, job segregation, and gendered bureaucracy, research related to gender has similarly taken prominence since the 1990s. However, age-related and cross-generational research escalated in the 2000s with the focus on succession planning and the inclusion of millennials (born after 1980) in the workforce. The post 9/11 era also saw a rise in research related to religion and veterans. The passage of the Americans With Disability Act in 1990 and the more recent Americans With Disability Act Amendments Act in 2008, focused attention on disability-related issues. Research related to sexual orientation gained momentum from the 2000s onwards; 24 articles on this topic were published in 2009- the year Employment Non-Discrimination Act (ENDA) was reintroduced in Congress. ENDA sought to prohibit employment discrimination based on one's sexual and gender identity. It appears that while race, gender, and AA continue to be investigated in the public administration literature, studies related to age, sexual orientation, disability, diversity management, and veterans are gaining impetus. In fact, research related to AA/EEO has been on the decline from 2010 to 2013. Statistical difference between groups is observed for these dimensions: gender, AA/EEO, representative bureaucracy, religion, SES, sexual orientation, and immigration across various decades.

\section{Gender Differences Across Diversity Research}

Interestingly, this study found gender differences based on the author's diversity focus. For example, female authors were significantly more likely to publish research related to gender and diversity management issues. The results are presented in Table 4 . While no statistical significance was found for other dimensions of diversity, female authors published more research than their male counterparts in the areas of EEO/AA, age, representative bureaucracy, religion, disability, and cultural competency. Male scholars were more likely than female authors to write about race, SES, sexual orientation, immigration, generations, and veterans.

What do these data mean? Trends indicate that research has kept up with the hot button issues reflecting AA/EEO, gender, age, and religion. Clearly, there has been a surge in diversity-related research post 1990 . However, is diversity just about numbers? Can it be that the imposition of various laws to promote diversity in the workplace has led to researchers examining these issues? Did concerns of equity and fairness only emerge post 1990 ? Is diversity about the number of articles published, the quality of journals, or scholar's diversity dimension? Have we reached a point of departure from issues related to gender and race? Is diversity about using econometric data and new modeling methods that help explain its impact on outcome variables such as performance and satisfaction? Should a qualitative lens that will delve into attitudes and perceptions about diversity be used to unpack what diversity really means for public administration? Furthermore, should inclusion be the new lens through 
Table 4. Mean Difference by Gender of the Author for Various Dimensions of Diversity.

\begin{tabular}{lcc}
\hline & Male (\%) $n=202$ & Female $(\%) n=142$ \\
\hline Race & 67 & 58 \\
Gender** & 49 & 67 \\
EEO/affirmative action & 27 & 33 \\
Age & 20 & 23 \\
Representative bureaucracy & 17 & 18 \\
Religion & 8 & 11 \\
Socioeconomic status & 9 & 8 \\
Disability & 6 & 9 \\
Sexual orientation & 8 & 6 \\
Diversity management* & 4 & 9 \\
Immigration & 5 & 4 \\
Generations & 5 & 4 \\
Veterans & 3 & 1 \\
Cultural competency & - & 1 \\
\hline
\end{tabular}

Note. EEO = equal employment opportunity.

$*_{p}<.05 . *_{p}<.01$.

which issues of social equity be examined? We hope that future researchers will examine these questions in more depth.

\section{Conclusion}

Since the Civil Rights Act of 1964, policy makers have devoted their energy and resources to defining and achieving fair representation of socially and politically important groups within the employee population of government (Greene, Selden, \& Brewer, 2000). Federal agencies have successfully increased workforce diversity by providing more opportunities of employment for women and racial/ethnic minorities through EEO and AA programs. Over the past decades, the demographic composition of the American workforce has been increasingly diversified, affected by civil rights legislation and AA programs (Choi \& Rainey, 2010). As a result, public organizations have been successful in diversifying their workforces by providing greater access to public jobs for women and racial/ethnic minorities (Cornwell \& Kellough, 1994; Foldy, 2004; Riccucci, 2002). Consequently, public organizations are experiencing unprecedentedly high demographic diversity or heterogeneity within the organizations. Some relevant studies also show that U.S. workers, particularly in the public sector, are becoming older and more diversified with respect to race/ethnicity and gender (Pitts, 2005) and as a result, an increased attention to management issues has arisen.

Our study finds that race is the most researched topic. With the recent police shootings in Ferguson, Cleveland, Chicago, Pennsylvania, Salt Lake City, and many others, we are reminded that race continues to be a big problem in this country. Instead of 
arguing for researchers to think beyond race, given the prevalence of research on race/ $\mathrm{AA} / \mathrm{EEO}$, perhaps the better question to ask is, Are we living in a postracial society or merely pushing these issues under the rug by hiding behind laws and AA? Just because we have several laws protecting people of color and minorities, are race problems that continue to pervade country been solved? A Kaiser Family Foundation study in 2015 reported that $49 \%$ of the people polled in the United States think that race is a greater problem today than it was 20 years ago. Even, stark are the responses by race- $66 \%$ Blacks and 64\% Hispanics report that racism is a big challenge today (DiJulio, Norton, Jackson, \& Brodie, 2015). Another study by Pew Research finds that $86 \%$ of Blacks report that more work remains before they can achieve equal rights as Whites (Drake, 2016). This study also finds similar numbers as reported by Kaiser Foundation's study wherein $50 \%$ of American's report race is a big problem facing our society today (up from $33 \%$ since 2010 ).

Going back to the research question posed, we can say from this study despite the focus on race, research on diversity in the field of public administration has progressed over time to reflect a changing society, and the laws and legislations developed to address structural and organizational inequalities and bias. Our research also shows that $P A R$ has taken the lead, publishing $30 \%$ of diversity-related research thereby establishing the relevance and importance of the concept in the field. As indicated in our research, the term diversity is clearly not only associated with race and gender. Rather, public administration as a discipline has cultivated a broader view of diversity that extends beyond issues of gender, race/ethnicity, AA, and representative bureaucracy to include disability, sexual orientation, religion, immigration, veterans, generations, diversity management and cultural competency, and SES (although some more than others). Apart from examining race and gender, future researchers can adopt a more synergistic view of diversity that values diversity in all its forms.

In terms of public administration research, even though dimensions of diversity research have broadened over time, these studies remain fundamentally descriptive in nature. Only $22 \%$ of the articles examined diversity as empirically related to outcomes. Notwithstanding the importance of descriptive research in setting forth why diversity is necessary in public organizations, empirical research provides the opportunity to link to the practice of public administration revealing what works and what changes need to me made. For example, Pitts and Wise (2010) maintained that empirical evidence is of particular importance when drafting policies that are redistributional in nature to understand the current distribution of resources and how changes will affect future distribution of resources. Future research should empirically examine and identify which tools to use (Pitts, 2010) to improve social equity by exploring some of the underrepresented dimensions of diversity identified in this study including cultural competency, veterans, generations, and immigration.

Future research can also explore the concept of inclusion in-depth using it both as an outcome and a predictor variable. Specifically, studies can examine the effects of inclusion on turnover, job satisfaction, performance, organizational commitment, and other outcome variables. Studies also can assess the impact of leadership, employee engagement, organizational climate, and culture among others on inclusion. Some 
scholars argue that diversity management is damaging to organizations because it detracts attention from discriminatory behavior that should be remedied first (Caudron \& Hayes, 1997; Cox, Lobel, \& McLeod, 1991; Morrison, 1992). Others maintain that diversity management is explored alongside continued emphasis on equity in recruitment, selection, and promotion and that it actually may assist in leveling the playing field for these groups (Naff \& Kellough, 2003). The looseness of the diversity management function leads to difficulty in operationalizing it for empirical research, resulting in little published research that considers the link between diversity management processes and performance in public sector organizations (Naff \& Kellough, 2003).

If diversity studies are to reflect 21 st-century society and beyond, scholars, more than ever before, need to understand and empirically study the intersection of diversity dimensions in a comparative context. Only $7 \%$ of the articles analyzed contained a comparative framework. As argued by Broadnax (2010), a comparative diversity perspective is becoming increasingly relevant to public administration research as the United States has become a critical player in a dynamic and evolving society defined by rapid globalization, immigration, interracial couples, and LGBT and biracial individuals and families. As the United States continues to grow more diverse, both the practice and research of public administration must keep pace with this new reality.

\section{Declaration of Conflicting Interests}

The author(s) declared no potential conflicts of interest with respect to the research, authorship, and/or publication of this article.

\section{Funding}

The author(s) received no financial support for the research, authorship, and/or publication of this article.

\section{References}

Andrews, R., Boyne, G. A., Meier, K. J., O’Toole, L. J., \& Walker, R. M. (2005). Representative bureaucracy, organizational strategy, and public service performance: An empirical analysis of English local government. Journal of Public Administration Research and Theory, $15,489-504$.

Broadnax, W. D. (2010). Diversity in public organizations: A work in progress. Public Administration Review, 70 (Suppl. 1), S177-S179.

Caleb, P. (2014). How diversity works. Scientific American, 311(4), 43-47.

Carrizales, T., \& Gaynor, T. S. (2013). Diversity in public administration research: A review of journal publications. Public Administration Quarterly, 37, 306-330.

Caudron, S., \& Hayes, C. (1997). Are diversity programs benefiting African Americans? Black Enterprise, 27, 121-136.

Cho, S., \& Mor Barak, M. E. (2008). Understanding of diversity and inclusion in a perceived homogeneous culture: A study of organizational commitment and job performance among Korean employees. Administration in Social Work, 32(4), 100-126. 
Choi, S., \& Rainey, H. G. (2010). Managing diversity in U.S. federal agencies: Effects of diversity and diversity management on employee perceptions of organizational performance. Public Administration Review, 70, 109-121. doi:10.1111/j.1540-6210.2009.02115.x

Christie, C. (2007). Content analysis. In R. Baumeister \& K. Vohs (Eds.), Encyclopedia of social psychology (p. 176). Thousand Oaks, CA: Sage.

Corley, E. A., \& Sabharwal, M. (2010). Scholarly collaboration and productivity patterns public administration: Analyzing recent trends. Public Administration, 88, 627-648.

Cornwell, C., \& Kellough, J. E. (1994). Women and minorities in federal government agencies: Examining new evidence from panel data. Public Administration Review, 54, 265-276.

Cox, T. H., Lobel, S. A., \& McLeod, P. L. (1991). Effects of ethnic group cultural differences on cooperative and competitive behavior on a group task. The Academy of Management Journal, 34, 827-847.

Denhardt, R. B., \& deLeon, L. (1995). Greater thinkers in personnel management. In J. Rabin, T. Vocino, B. Hildreth \& G. Miller (Eds.), Handbook of public personnel administration (pp. 21-41). New York, NY: Marcel Dekker.

DiJulio, B., Norton, M., Jackson, S., \& Brodie, M. (2015). Kaiser Family Foundation/CNN Survey of Americans on race. Retrieved from http://files.kff.org/attachment/report-surveyof-americans-on-race

Drake, B. (2016). Five facts about race in America. Pew Research Center. Retrieved from http:// www.pewresearch.org/fact-tank/2016/01/18/5-facts-about-race-in-america/

Ferdman, B. M., Avigdor, A., Braun, D., Konkin, J., \& Kuzmycz, D. (2010). Collective experience of inclusion, diversity, and performance in work groups. RAM-Revista de Administração Mackenzie, 11(3), 6-26.

Findler, L., Wind, L. H., \& Mor Barak, M. E. (2007). The challenge of workforce management in a global society: Modeling the relationship between diversity, inclusion, organizational culture, and employee well-being, job satisfaction and organizational commitment. Administration in Social Work, 31(3), 63-94.

Foldy, E. G. (2004). Learning from diversity: A theoretical exploration. Public Administration Review, 64, 529-538. doi:10.1111/j.1540-6210.2004.00401.x

Frederickson, H. G. (1980). New public administration. AL: University of Alabama Press.

Frederickson, H. G.(1990). Public Administration and Social Equity. Public Administration Review, 50, 228-237.

Frederickson, H. G. (2005). The state of social equity in American public administration. National Civic Review, 94, 31-38. doi:10.1002/ncr.117

Gilbert, J. A., \& Ivancevich, J. M. (2000). Valuing diversity: A tale of two organizations. The Academy of Management Executive, 14, 93-105.

Gooden, S., \& Portillo, S. (2011). Advancing social equity in the Minnowbrook tradition. Journal of Public Administration Research and Theory, 21(Suppl. 1), i61-i76.

Grabosky, P. N., \& Rosenbloom, D. H. (1975). Racial and ethnic integration in the federal service. Social Science Quarterly, 56, 71-84.

Greene, V., Selden, S. C., \& Brewer, G. (2000). Measuring power and presence: Bureaucratic representation in the American states. Journal of Public Administration Research and Theory, 11, 379-402.

Groeneveld, S., \& Van de Walle, S. (2010). A contingency approach to representative bureaucracy: Power, equal opportunities and diversity. International Review of Administrative Sciences, 76, 239-258. 
Hall, G., \& Saltzstein, A. (1977). Equal employment opportunity for minorities in municipal government. Social Science Quarterly, 57, 864-872.

Hewins-Maroney, B., \& Williams, E. (2013). The role of public administrators in responding to changing workforce demographics: Global challenges to preparing a diverse workforce. Public Administration Quarterly, 37, 456-490.

Hindera, J. J. (1993). Representative bureaucracy: Further evidence of active representation in the EEOC district offices. Journal of Public Administration Research and Theory, 3, 415-429.

Johnson, G., Johnson, N. J., \& Svara, J. H. (2015). Justice for all: Promoting social equity in public administration. New York, NY: Routledge.

Keiser, L. R., Wilkins, V. M., Meier, K. J., \& Holland, C. (2002). Lipstick and logarithms: Gender, institutional context, and representative bureaucracy. American Political Science Review, 96, 553-564.

Kellough, J. E. (1990). Integration in the public workplace: Determinants of minority and female employment in federal agencies. Public Administration Review, 50, 557-566.

Kellough, J. E., \& Naff, K. C. (2004). Managing diversity in the federal service: Responding to a wake-up call. Administration \& Society, 36, 62-90.

Kellough, J. E., \& Pitts, D. W. (2005). Who contributes to public administration review? Examining the characteristics of authors who submit manuscripts to the journal. Public Administration Review, 65, 3-7.

Kingsley, J. D. (1944). Representative bureaucracy. Yellow Springs, OH: Antioch Press.

Krislov, S. (1974). Representative bureaucracy. Englewood Cliffs, NJ: Prentice Hall.

Mathews, A. (1998). Diversity: A principle of human resource management public personnel management, 27, 175-185.

Meier, K. J. (1975). Representative bureaucracy: An empirical analysis. American Political Science Review, 69, 526-542.

Meier, K. J. (1993). Latinos and representative bureaucracy: Testing the Thompson and Henderson hypotheses. Journal of Public Administration Research and Theory, 3, 393-415.

Meier, K. J., \& Bohte, J. (2001). Structure and discretion: Missing links in representative bureaucracy. Journal of Public Administration Research and Theory, 11, 455-470.

Meier, K. J., \& Nigro, L. G. (1976). Representative bureaucracy and policy preferences: A study in the attitudes of federal executives. Public Administration Review, 36, 458-469.

Meier, K. J., \& Stewart, J., Jr. (1992). The impact of representative bureaucracies: Educational systems and public policies. The American Review of Public Administration, 22, 157-171.

Meier, K. J., Stewart, J., Jr., \& England, R. (1989). Race, class and education: The politics of second-generation discrimination. Madison, WI: University of Wisconsin Press.

Meier, K. J., Wrinkle, R. D., \& Polinard, J. L. (1999). Representative bureaucracy and minority student performance: The interaction of resources and representation. Journal of Public Management and Social Policy, 5(Summer), 85-96.

Mladenka, K. R. (1991). Public employee unions, reformism, and Black employment in 1,200 American cities. Urban Affairs Review, 26, 532-548.

Mor Barak, M. E., \& Cherin, D. (1998). A tool to expand organizational understanding of workforce diversity. Administration in Social Work, 22, 47-64.

Mor Barak, M. E., \& Levin, A. (2002). Outside of the corporate mainstream and excluded from the work community: A study of diversity, job satisfaction and well-being. Community, Work \& Family, 5, 133-157. 
Morrison, A. M. (1992). The new leaders: Guidelines on leadership diversity in America (Jossey-Bass Management Series). San Francisco, CA: Jossey-Bass.

Mosher, F. C. (1982). Democracy and the public service (2ne ed.), New York, NY: Oxford University Press.

Muñoz, S. R., \& Bangdiwala, S. I. (1997). Interpretation of Kappa and B statistics measures of agreement. Journal of Applied Statistics, 24, 105-112.

Nachmias, D., \& Rosenbloom, D. H. (1973). Measuring bureaucratic representation and integration. Public Administration Review, 33, 590-597.

Naff, K. C., \& Kellough, J. E. (2003). Ensuring employment equity: Are federal diversity programs making a difference? International Journal of Public Administration, 26, 1307-1336.

Obergefell v. Hodges, 576 U.S. (2015).

Pitkin, H. F. (1967). The concept of representation. Berkeley: University of California Press.

Pitts, D. W. (2005). Diversity, representation, and performance: Evidence about race and ethnicity in public organizations. Journal of Public Administration Research and Theory, 15, 615-631.

Pitts, D. W. (2006). Modeling the impact of diversity management. Review of Public Personnel Administration, 26, 245-268.

Pitts, D. W. (2009). Diversity management, job satisfaction, and performance: Evidence from U.S. federal agencies. Public Administration Review, 69, 328-338.

Pitts, D. W. (2011). A little less conversation, a little more action: Using empirical research to promote social equity. Journal of Public Administration Research and Theory, 21(Suppl. 1), i77-i82.

Pitts, D. W., \& Jarry, E. M. (2005). Ethnic diversity and organizational performance: Assessing diversity effects at the managerial and street levels (Andrew Young School of Policy Studies Research Paper No. 06-33). Retrieved from http://ssrn.com/abstract=895314

Pitts, D. W., \& Wise, L. R. (2010). Workforce diversity in the new millennium: Prospects for Research. Review of Public Personnel Administration, 30, 44-69.

Raadschelders, J. C. N., \& Lee, K. H. (2011). Trends in the study of public administration: Empirical and qualitative observations from Public Administration Review, 2000-2009, 71, 19-33.

Riccucci, N. M. (2002). Managing diversity in public sector workforces. Boulder, CO: Westview Press.

Riccucci, N. M. (2009). The pursuit of social equity in the federal government: A road less traveled? Public Administration Review, 69, 373-382.

Rosenbloom, D. H. (1977). Federal equal employment opportunity: Politics and public personnel administration. Westport, CT: Praeger.

Rosenbloom, D. H. (2005). Taking social equity seriously in MPA education. Journal of Public Affairs Education, 11, 247-252.

Rourke, J. T. (1978). The GAO: An evolving role. Public Administration Review, 38, 453-457.

Sabharwal, M. (2014). Is diversity management sufficient? Organizational inclusion to further performance. Public Personnel Management, 43, 197-217.

Selden, S. C. (1997). The promise of representative bureaucracy: Diversity and responsiveness in a government agency. Armonk, NY: M.E. Sharpe.

Selden, S. C., Brudney, J. L., \& Kellough, J. E. (1998). Bureaucracy as a representative institution: Toward a reconciliation of bureaucratic government and democratic theory. American Journal of Political Science, 42, 717-744. 
Shields, P., \& Rangarajan, N. (2013). A playbook for research methods: Integrating conceptual frameworks and project management. Stillwater, OK: New Forum

Sowa, J. E., \& Selden, S. C. (2003). Administrative discretion and active representation: An expansion of the theory of representative bureaucracy. Public Administration Review, 63, 700-710.

Thomas, R. R. (1990). From affirmative action to affirming diversity. Harvard Business Review, 68, 107-117.

Welch, S., Karnig, A. K., \& Eribes, R. A. (1983). Correlates of women's employment in local governments. Urban Affairs Review, 18, 551-564.

Wise, L. R., \& Tschirhart, M. (2000). Examining empirical evidence on diversity effects: How useful is diversity research for public sector managers? Public Administration Review, 60, 386-394.

\section{Author Biographies}

Meghna Sabharwal is associate professor and $\mathrm{PhD}$ advisor in the public and nonprofit management program at the University of Texas at Dallas. Her research interests are focused on public human resources management, specifically workforce diversity, job performance, job satisfaction, and high-skilled migration. She is widely published in public administration journals. She also has two book publications: Public Personnel Administration (6th Ed.) and Public Administration in South Asia: India, Bangladesh, and Pakistan. She won the 2016 University of Texas at Dallas Inclusive Excellence and Intercultural Engagement Teaching Award. She is also the 2015 recipient of the Julia J. Henderson International Award (2015) by the American Society for Public Administration (ASPA) Section on Women in Public Administration.

Helisse Levine is associate professor and director of the MPA Program Long Island University, School of Business, Public Administration and Information Sciences. She earned her $\mathrm{PhD}$ in public administration from School of Public Affairs and Administration, Rutgers University, Newark, N.J. in 2005. Her research interests include the role of fiscal constraints and gender inequities in public organizations. Since entering academe she has contributed to many public administration and finance journals. She is co-editor of both the Handbook of Local Government Fiscal Health and Women in Public Administration: Theory and Practice. Dr. Levine served as Board Member to the New York Chapter of the American Society of Public Administration (ASPA), Section on Women in Public Administration (SWPA), and Section on Budgeting and Financial Management (ABFM). She was recipient of LIU's 2014 Newton Excellence in Teaching Award and the 2014 Dr. Rita Mae Kelly (1939-2001) Distinguished Research Award, ASPA Section for Women in Public Administration.

Maria D'Agostino is chair and associate professor in the Department of Public Management at John Jay College of Criminal Justice. Dr. D'Agostino's recent research has focused on women in public service including a co-edited book, Women and Public Administration: Theory and Practice. Maria D'Agostino is a recipient of the Section for Women in Public Administration Rita Mae Kelly Distinguished Research Award. She is also a member of the UNDP roster of experts in Gender Equality and Women's Empowerment in Public Administration and co-founder of Women in the Public Sector at John Jay College. Maria D'Agostino is currently working on a solo authored book that aims to understand the difference women make in New York City Public Administration and a co-edited volume that examines the role of women in public administration from a global perspective. She is also co-editing the forthcoming Administration \& Society Women and Public Administration symposium and is a recipient of the Faculty Mid-Career Research Award. 